\title{
Organizational diagnostics of the farm
}

\author{
Ekaterina Alpatova1, ${ }^{1, *}$ Nana Chkhutiashvili ${ }^{2}$, Ludmila Goloshchapova ${ }^{3}$, and Olga \\ Kovalenkova ${ }^{4}$ \\ ${ }^{1}$ State University of Management, 99, Ryazan Ave., 109542, Moscow, Russia \\ ${ }^{2}$ Kutafin Moscow State Law University (MSAL), 9, Sadovaya-Kudrinskaya str., 125993, Moscow, \\ Russia \\ ${ }^{3}$ Russian University of Economics named after G. V. Plekhanov, 36, Stremyanny Lane, 117997, \\ Moscow, Russia \\ ${ }^{4}$ Don State Technical University, 1, Gagarin Sq., 344003, Rostov-on-Don, Russia
}

\begin{abstract}
In this paper is transformation of traditional organizational diagnostics for the use organizations in the field of agribusiness. The transformation of the methodology is necessary due to the peculiarities of the functional zones of the farm, associated with a limited number of human resources in the state of such an organization, taking into account the fact that each unit of the state will have expanded professional competencies to overlap the functionality of the main organizational zones. The paper uses a methodology for developing diagnostic tables that reveal the degree of severity of the main characteristics with the development of an individual typology for the farm, which allows to identify the root problems of the activity; a diagnostic profile is built, the correlation of the identified problems is carried out using expert analysis. In the course of the work, six key functional zones were identified, the analysis of which allows us to diagnose the state of the farm at the current time and formulate the degree of problems and the presence of bottlenecks that require operational management influence. The algorithm developed in this paper is universal for conducting a comprehensive analysis and diagnosis of the state of farming.
\end{abstract}

\section{Introduction}

Agribusiness in Russia is currently going through difficult transformational times. The key component of the agrosphere is the farm, which has a number of features that distinguish it from other agribusiness organizations. Farms in Russia emerged against the background of the destruction of the Soviet system of collective farms and state farms, when collective and state ownership was replaced by private property. Both the first farms and those that appear in the future are built on the principle of nepotism. And, of course, given the small size of the staff of such organizations, a special role is played by the multifaceted professional competencies of the human resources of the farm, which literally turn into human capital, when analyzing the labor participation rate of employees in each functional zone. The principle of conducting organizational diagnostics for a farm is typical [1-6] (Fig. 1), but,

\footnotetext{
*Corresponding author :katrin.alpatova@mail.ru
} 
due to the above-described feature of the degree of staff participation in all functional areas of the farm, it has individual features. The management of an organization in the field of agribusiness is associated with the specifics of agriculture, namely: the dependence of obtaining commercial results on the state of the natural environment, on the role and importance of the products produced by the agricultural firm, the inconsistency of the working period and the period of agricultural production, the seasonality of agricultural production and receipt of products, on the level of development of foreign economic relations (with suppliers of feed, fertilizers, seeds, etc.), as well as state influence on the development of agribusiness.

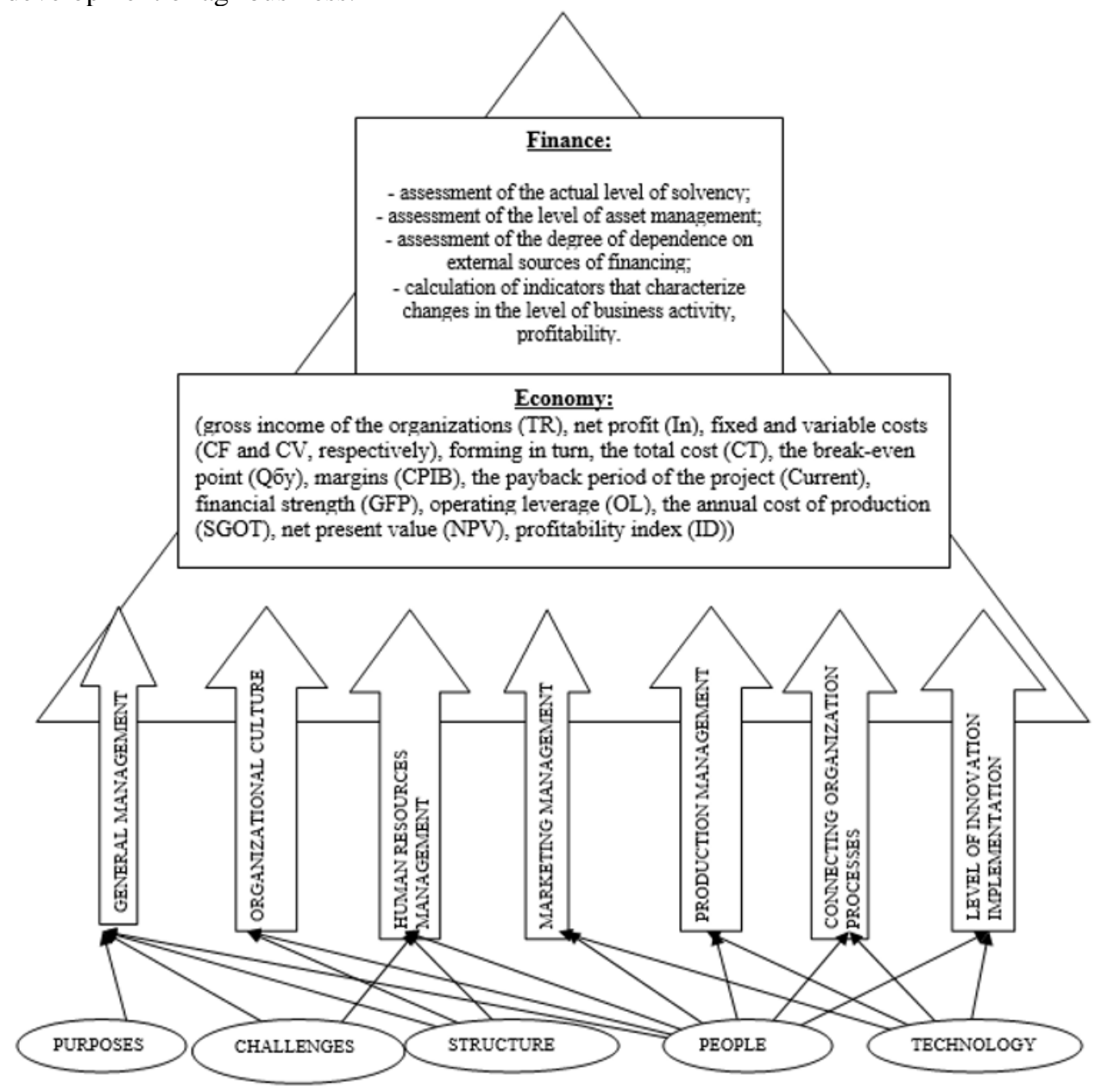

Fig. 1. The relationship of cause and effect in diagnostic analysis organization management [1].

Let's consider the range of key features that determine the company's management system in the agricultural sphere:

- the management of an agricultural firm assumes a special socio-economic approach to the goods produced, since they are essential goods for a person, and are needed in a timely manner, in the required volume and breadth of the assortment, are transformed by the demographic characteristics of consumers and the associated food culture. The products produced must take into account the characteristics of potential consumers, taking into account age criteria; gender; national, regional, religious traditions; the state of health and lifestyle of consumers in order to fully meet their needs and interests. And the 
economic approach consists of: taking into account the fact that the product is perishable (in this regard, a careful calculation of the cost and market price is necessary); analysis of potential demand; well-established storage and logistics systems, the required aesthetic packaging, and many others;

- taking into account the inconsistency of the working period and the production period, namely, in crop production, finished products in Russia are received once - once in a calendar year, but the working year lasts a full calendar year, (in this regard, it is necessary to carefully predict demand, consumer preferences, taking into account seasonality, etc.);

- $\quad$ taking into account natural and climatic factors, since agriculture is always closely related to land use, which will ultimately determine the potential volume of agricultural products, the diversity of its range and the level of product quality;

a high level of competition, due to the identity of products, including those associated with the aggressive policy of foreign suppliers of agricultural products and many others.

Thus, a special system of components is formed to describe specific functional zones, the management vector, and a special component - the organizational culture and management style of the agricultural firm for conducting organizational diagnostics of the farm:

- $\quad$ production of agricultural products;

- $\quad$ agromarketing and logistics of agricultural products;

- financial activity of the agricultural firm;

- general principles of agricultural firm management;

- $\quad$ management style of an agricultural firm;

- organizational culture of the agricultural firm.

Each of the functional zones has a lexical description by highlighting the characteristics that reflect the specific state of each zone. Each of the states is assigned a specific diagnostic level, selected from 8 diagnostic states: 4 with the «+» sign, 4 with the «-» sign. Each of the selected 6 functional zones is diagnosed by assigning lexical characteristics to a specific state, according to the results of a comprehensive analysis, a diagnostic conclusion is made to the state of the agricultural enterprise at this current time. To obtain more objective data, this analysis is of a collective nature - the diagnoses of the organization are made with the help of a group of experts, both from the organization itself and from external consultants. It is typical for a farm to involve the entire group of managers and owners of agribusiness, since often a farm business is a small business and a family business, then to involve as experts all family members-owners and at the same time farm workers.

\section{Materials, Methods and Results}

As a sample base, 50 objects of agricultural enterprises were considered: 30 farms of the Rostov region and 20 farms of the Krasnodar Territory. On the basis of the data obtained by the researchers, a generalized version was formed, universal diagnostic tables were created that are suitable for use by the researcher when conducting organizational diagnostics of a farm [7] and making a diagnosis at the current time.

Diagnostic tables are classifying states for each functional area of the enterprise with descriptive characteristics in accordance with each state. Based on the analysis of each functional zone, experts make a decision, which, then, using the use of expert analysis and determining the degree of correlation between the obtained estimates, is brought to a single decision on a comprehensive analysis of the activities of the farm. The descriptive characteristics of the states were selected by the authors of the work in the process of 
forming the basis for conducting a sample of farms, both successful and in pre-crisis and crisis states, which provided researchers with a rich basis for the formation of universal diagnostic tables 1-6, designed for conducting organizational diagnostics of farms.

Table 1. Agricultural production

\begin{tabular}{|c|c|c|c|}
\hline $\begin{array}{l}\text { Stage } \\
\mathrm{S}^{+}\end{array}$ & The phase of decline and crisis & Stabilization and recovery phase & $\begin{array}{l}\text { Sta } \\
\text { ges }\end{array}$ \\
\hline$S_{1^{-}}$ & $\begin{array}{l}\text { The lack of rational proposals for the } \\
\text { development of the agro range, } \\
\text { problems with the technological cycle } \\
\text { and calendar schedule, the beginning } \\
\text { of a drop in profits }\end{array}$ & $\begin{array}{l}\text { Rationalization measures, increased } \\
\text { investment in product range expansion, } \\
\text { profit growth }\end{array}$ & $S_{1}^{+}$ \\
\hline$S_{2}^{-}$ & $\begin{array}{l}\text { The lack of new production solutions } \\
\text { programs, static assortment, part of } \\
\text { the equipment is constantly under } \\
\text { repair, the first losses }\end{array}$ & $\begin{array}{l}\text { Systematic planning and introduction of } \\
\text { new products in the range of agricultural } \\
\text { products, optimization of technological } \\
\text { chains, development of methods for } \\
\text { quality control of agricultural products }\end{array}$ & $S_{2}{ }^{+}$ \\
\hline$S_{3}^{-}$ & $\begin{array}{l}\text { Increasing problems with the } \\
\text { expansion of the assortment line of } \\
\text { agricultural products, } \\
\text { falling profitability of agricultural } \\
\text { products, regular equipment } \\
\text { breakdowns, constant disruptions of } \\
\text { the calendar schedule, significant } \\
\text { losses }\end{array}$ & $\begin{array}{l}\text { Expanding the range of agricultural } \\
\text { products, increasing the profitability of } \\
\text { most assortment items, the work of the } \\
\text { initiative group on certain categories of } \\
\text { agricultural products }\end{array}$ & $S_{3}{ }^{+}$ \\
\hline$S_{4}^{-}$ & $\begin{array}{l}\text { Reduced filling of the assortment line } \\
\text { of agricultural products, a decrease in } \\
\text { the number of customers, an increase } \\
\text { in the inventory of agricultural } \\
\text { products, only a small part of the } \\
\text { production equipment and machinery } \\
\text { is in working condition, threatening } \\
\text { losses }\end{array}$ & $\begin{array}{l}\text { Achieving sustainable competitive } \\
\text { advantages and a leading position in the } \\
\text { market, improving the quality of service } \\
\text { based on the application of the "just-in- } \\
\text { time" principle, the principle of integrated } \\
\text { quality control, the principle of integrated } \\
\text { repair and preventive maintenance, as } \\
\text { well as planning the aggregated output of } \\
\text { production tools for operational } \\
\text { production management and the constant } \\
\text { use of the Gantt accounting and planning } \\
\text { schedule }\end{array}$ & $S_{4}^{+}$ \\
\hline
\end{tabular}

Table 2. Agromarketing and logistics

\begin{tabular}{|l|l|l|l|}
\hline $\begin{array}{l}\text { Stag } \\
\text { es }^{+}\end{array}$ & The phase of decline and crisis & Stabilization and recovery phase & $\begin{array}{l}\text { Sta } \\
\text { ges }\end{array}$ \\
\hline$S_{1}-$ & $\begin{array}{l}\text { The study of market conditions is } \\
\text { superficial; the agricultural firm adheres to } \\
\text { old product lines that are well known in } \\
\text { the market and the assortment line is } \\
\text { stagnating; the market share is declining; } \\
\text { competitors are beginning to outperform in } \\
\text { some types of agricultural products; the } \\
\text { first problems with sales and suppliers }\end{array}$ & $\begin{array}{l}\text { Introduction of new agricultural } \\
\text { products to the market in small } \\
\text { quantities; search and formation of } \\
\text { novelties of agricultural products- } \\
\text { consumer needs, constant study of } \\
\text { market conditions }\end{array}$ & $S_{1^{+}}$ \\
\hline$S_{2}-$ & $\begin{array}{l}\text { Reduced sales of agricultural products, the } \\
\text { loss of a part of the sales markets for } \\
\text { agricultural products, the lack of }\end{array}$ & $\begin{array}{l}\text { Gaining new market positions by } \\
\text { adjusting to the tastes and preferences } \\
\text { of potential consumers; building }\end{array}$ & $S_{2}$ \\
\hline
\end{tabular}




\begin{tabular}{|c|c|c|c|}
\hline $\begin{array}{l}\text { Stag } \\
\text { es }^{+}\end{array}$ & The phase of decline and crisis & Stabilization and recovery phase & $\begin{array}{l}\text { Sta } \\
\text { ges }\end{array}$ \\
\hline & $\begin{array}{l}\text { advertising activities and market } \\
\text { demographic statistics; a drop in the level } \\
\text { of product quality }\end{array}$ & $\begin{array}{l}\text { work with suppliers according to } \\
\text { their own calendar schedule; } \\
\text { exploring possible channels for } \\
\text { increasing sales of agricultural } \\
\text { products }\end{array}$ & \\
\hline$S_{3}{ }^{-}$ & $\begin{array}{l}\text { Loss of a significant market share of } \\
\text { agricultural products, lack of a marketing } \\
\text { strategy, market research is not conducted } \\
\text { constantly; weak sales; low level of } \\
\text { interaction with suppliers, many supply } \\
\text { disruptions, product quality suffers (due to } \\
\text { a lack of timely delivery of fertilizers, for } \\
\text { example) }\end{array}$ & $\begin{array}{l}\text { The sales volume is growing rapidly, } \\
\text { information about market saturation } \\
\text { opportunities is constantly analyzed, } \\
\text { advertising of agricultural products is } \\
\text { widely used; new types of delivery } \\
\text { and packaging of agricultural } \\
\text { products are developed }\end{array}$ & $S_{3}{ }^{+}$ \\
\hline$S_{4}{ }^{-}$ & $\begin{array}{l}\text { Indifference to a potential buyer, } \\
\text { unwillingness to change the methods of } \\
\text { work in the agricultural market, as well as } \\
\text { old suppliers of goods; loss of a significant } \\
\text { market share; poor quality of many types } \\
\text { of products; losses }\end{array}$ & $\begin{array}{l}\text { The gained positions in the market } \\
\text { are maintained at a high level; the } \\
\text { level of sales is steadily growing, } \\
\text { more profitable suppliers are found; } \\
\text { market research and development is } \\
\text { conducted on an ongoing basis, their } \\
\text { results adjust the volume of } \\
\text { production of various types of } \\
\text { agricultural products; pre-sale } \\
\text { customer service is established; } \\
\text { active advertising promotion of } \\
\text { products; growing profits }\end{array}$ & $S_{4}^{+}$ \\
\hline
\end{tabular}

Table 3. Financial activities

\begin{tabular}{|l|l|l|l|}
\hline $\begin{array}{l}\text { Stag } \\
\text { es }\end{array}$ & The phase of decline and crisis & Stabilization and recovery phase & $\begin{array}{l}\text { Sta } \\
\text { ges } \\
-\end{array}$ \\
\hline$S_{1^{-}}$ & Lower profits & $\begin{array}{l}\text { Gradual increase in revenue decrease in } \\
\text { profit }\end{array}$ & $\begin{array}{l}S_{1} \\
+\end{array}$ \\
\hline$S_{2}-$ & $\begin{array}{l}\text { Falling planned sales, first losses, } \\
\text { cash constraints }\end{array}$ & $\begin{array}{l}\text { Stable financial position of the agricultural } \\
\text { company in the market, constant profit } \\
\text { growth, growth of the agricultural company } \\
\text { due to the increase in acreage and } \\
\text { greenhouse areas }\end{array}$ & $\begin{array}{l}S_{2} \\
+\end{array}$ \\
\hline$S_{3}-$ & $\begin{array}{l}\text { A sharp decrease in the financial } \\
\text { reserve, an increase in stocks of } \\
\text { agricultural products in warehouses, } \\
\text { tangible losses }\end{array}$ & $\begin{array}{l}\text { Increase in sales volumes due to the growth } \\
\text { of the customer base, the growth of the } \\
\text { reserve financial fund }\end{array}$ & $\begin{array}{l}S_{3} \\
+\end{array}$ \\
\hline$S_{4}-$ & $\begin{array}{l}\text { A sharp decrease in profit, a drop in } \\
\text { sales, a reduction in acreage and } \\
\text { greenhouse area }\end{array}$ & $\begin{array}{l}\text { An increase in the share of own funds in the } \\
\text { capital of an agricultural firm, an increase in } \\
\text { business activity; a multiple increase in sales } \\
\text { volumes, entry into the «normal» corridor } \\
\text { and compliance with all financial indicators } \\
\text { [1-2] }\end{array}$ & $\begin{array}{l}S_{4} \\
+\end{array}$ \\
\hline
\end{tabular}


Table 4. General principles of agricultural firm management

\begin{tabular}{|c|c|c|c|}
\hline $\begin{array}{l}\text { Stage } \\
\mathrm{S}^{+}\end{array}$ & The phase of decline and crisis & Stabilization and recovery phase & $\begin{array}{l}\text { Sta } \\
\text { ge } \\
\text { - }\end{array}$ \\
\hline $\mathrm{S}_{1}^{-}$ & $\begin{array}{l}\text { Dismissal of qualified employees } \\
\text { offering the introduction of } \\
\text { innovations in the activities of } \\
\text { agricultural firms }\end{array}$ & $\begin{array}{l}\text { Development of measures aimed at } \\
\text { increasing and stable growth of sales } \\
\text { volume }\end{array}$ & $\begin{array}{l}\mathrm{S}_{1} \\
+\end{array}$ \\
\hline $\mathrm{S}_{2}{ }^{-}$ & $\begin{array}{l}\text { Development of measures to reduce } \\
\text { the cost of developing the activities } \\
\text { of the agricultural firm, constant } \\
\text { staff turnover }\end{array}$ & $\begin{array}{l}\text { Adoption of employee initiatives, } \\
\text { promotion of well-coordinated work of } \\
\text { the team, implementation of customer- } \\
\text { oriented principles }\end{array}$ & $\begin{array}{l}\mathrm{S}_{2} \\
+\end{array}$ \\
\hline $\mathrm{S}_{3}{ }^{-}$ & $\begin{array}{l}\text { Market analysis is not carried out, } \\
\text { there is no clear idea of the buyer's } \\
\text { preferences; biased assessment of } \\
\text { the internal potential by the owners } \\
\text { of agribusiness, the first losses }\end{array}$ & $\begin{array}{l}\text { Continuous analysis of the market, study } \\
\text { of food prices and preferences of potential } \\
\text { consumers, involvement of external } \\
\text { consultants for a more objective } \\
\text { assessment of the market and drawing up } \\
\text { a portrait of a regular customer; } \\
\text { implementation of the principles of } \\
\text { effective team building in the activities of } \\
\text { an agricultural firm }\end{array}$ & $\begin{array}{l}\mathrm{S}_{3} \\
+\end{array}$ \\
\hline $\mathrm{S}_{4}^{-}$ & $\begin{array}{l}\text { The management is conservative, } \\
\text { does not want to change either } \\
\text { management methods or production } \\
\text { methods, refuses to introduce } \\
\text { agromarketing, does not accept the } \\
\text { use of new methods to increase and } \\
\text { stimulate sales, losses }\end{array}$ & $\begin{array}{l}\text { Development of a new system for } \\
\text { stimulating staff work, active team } \\
\text { building, conducting a detailed market } \\
\text { study, developing new approaches to the } \\
\text { consumer and forming the «right» } \\
\text { agricultural assortment }\end{array}$ & $\begin{array}{l}\mathrm{S}_{4} \\
+\end{array}$ \\
\hline
\end{tabular}

Table 5. Management style of an agricultural firm

\begin{tabular}{|c|c|c|c|}
\hline $\begin{array}{l}\text { Stag } \\
\text { es }^{+}\end{array}$ & $\begin{array}{l}\text { The phase of decline and } \\
\text { crisis }\end{array}$ & Stabilization and recovery phase & $\begin{array}{l}\text { Sta } \\
\text { ges }\end{array}$ \\
\hline $\mathrm{S}_{1^{-}}$ & $\begin{array}{l}\text { Lack of clear development } \\
\text { goals and strategies }\end{array}$ & $\begin{array}{l}\text { Management sets clear goals and carefully monitors } \\
\text { their implementation }\end{array}$ & $\begin{array}{l}\mathrm{S}_{1} \\
+\end{array}$ \\
\hline $\mathrm{S}_{2}{ }^{-}$ & $\begin{array}{l}\text { Power struggle instead of } \\
\text { cooperation }\end{array}$ & $\begin{array}{l}\text { Introduction of activity planning, fruitful } \\
\text { cooperation with team members, suppliers and } \\
\text { customers; start of work of initiative groups for the } \\
\text { development of innovations for agricultural firms }\end{array}$ & $\begin{array}{l}\mathrm{S}_{2} \\
+\end{array}$ \\
\hline $\mathrm{S}_{3}{ }^{-}$ & $\begin{array}{l}\text { Management's indifference } \\
\text { to subordinates, general } \\
\text { fatigue, lack of energy to } \\
\text { make changes and } \\
\text { improvements }\end{array}$ & $\begin{array}{l}\text { Proactive actions are implemented to increase the } \\
\text { market share and win over competitors; continuous } \\
\text { specialized professional development of team } \\
\text { members }\end{array}$ & $\begin{array}{l}\mathrm{S}_{3} \\
+\end{array}$ \\
\hline $\mathrm{S}_{4}{ }^{-}$ & $\begin{array}{lr}\text { Anarchy } & \text { (bad attitude } \\
\text { towards } & \text { customers, } \\
\text { suppliers, } & \text { rudeness in } \\
\text { disputes); } & \text { constant } \\
\text { aggression and anxiety }\end{array}$ & $\begin{array}{l}\text { The entire staff of the agricultural firm is a team; } \\
\text { the owners and employees establish relationships } \\
\text { based on trust, implement the principles of self- } \\
\text { organization of management associated with a high } \\
\text { level of responsibility of team members; there is a } \\
\text { constant study of the market in order to determine } \\
\text { and use the favorable market conditions: planning } \\
\text { the necessary measures to create a new assortment } \\
\text { of agricultural products }\end{array}$ & $\begin{array}{l}\mathrm{S}_{4} \\
+\end{array}$ \\
\hline
\end{tabular}


Table 6. Organizational culture of an agricultural firm

\begin{tabular}{|c|c|c|c|}
\hline $\begin{array}{l}\text { Stag } \\
\text { es }^{+}\end{array}$ & The phase of decline and crisis & Stabilization and recovery phase & $\begin{array}{l}\text { Sta } \\
\text { ge } \\
\text { S- }\end{array}$ \\
\hline $\mathrm{S}_{1}^{-}$ & $\begin{array}{l}\text { Non-constructive influence of } \\
\text { subordinates on the management } \\
\text { and directive management of } \\
\text { subordinates, insufficient } \\
\text { qualification of employees }\end{array}$ & $\begin{array}{l}\text { Eliminating customer losses due to internal } \\
\text { contradictions and friction between } \\
\text { employees, overriding the goals of the } \\
\text { organization over personal ones }\end{array}$ & $\begin{array}{l}\mathrm{S}_{1} \\
+\end{array}$ \\
\hline $\mathrm{S}_{2}{ }^{-}$ & $\begin{array}{l}\text { Harassment of capable employees, } \\
\text { reducing the actions of employees to } \\
\text { clearly structured actions }\end{array}$ & $\begin{array}{l}\text { Selection of highly qualified employees } \\
\text { who take the role of each team member } \\
\text { depending on the situation, maintaining the } \\
\text { corporate spirit and well-coordinated work } \\
\text { of the team }\end{array}$ & $\begin{array}{l}\mathrm{S}_{2} \\
+\end{array}$ \\
\hline $\mathrm{S}_{3}{ }^{-}$ & $\begin{array}{l}\text { All attempts to make changes to } \\
\text { improve the work are considered } \\
\text { hindrances, the owners of the } \\
\text { agricultural firm consider } \\
\text { themselves highly competent and do } \\
\text { not need additional assessments and } \\
\text { suggestions for the development of } \\
\text { agribusiness }\end{array}$ & $\begin{array}{l}\text { Implementation of the KPI system to } \\
\text { improve the efficiency of the agricultural } \\
\text { firm and create a bonus program for staff, } \\
\text { thus-stimulating employees based on the } \\
\text { results of their work, encouraging the } \\
\text { manifestation of initiatives }\end{array}$ & $\begin{array}{l}\mathrm{S}_{3} \\
+\end{array}$ \\
\hline $\mathrm{S}_{4}{ }^{-}$ & $\begin{array}{l}\text { There is the pursuit of only personal } \\
\text { goals, chaos, and constant staff } \\
\text { turnover }\end{array}$ & $\begin{array}{l}\text { Participation of employees in decision- } \\
\text { making aimed at the development of the } \\
\text { company's activities, conscious teamwork, } \\
\text { democratic style of employee management }\end{array}$ & $\begin{array}{l}\mathrm{S}_{4} \\
+\end{array}$ \\
\hline
\end{tabular}

Traditional organizational diagnostics [1-6] uses a collective assessment by a group of experts [8], and then the results obtained from each expert are averaged, the variance is calculated, and then the consistency of experts is calculated using the coefficient of variation and a diagnostic profile is built that reflects the «bottlenecks» in various aspects of the organization, determining the state of the agricultural firm at the present time. But, as mentioned earlier, farming often has the character of a family business and a small enterprise, so there are not so many decision makers and responsibility for their implementation. For a farm, it is proposed to collect estimates using survey tables from all staff, thereby supplementing information about the individual state of the farm in the developed universal tables, and then the farm owner will act as a decision-maker when assigning his agricultural enterprise to a specific diagnostic state for all key components.

\section{Results}

In the course of the study, the authors developed a special algorithm for conducting organizational diagnostics of a farm, consisting of 6 diagnostic tables that allow you to determine 8 diagnostic states of 6 key functional zones of agribusiness management. The diagnostic algorithm is based on the formation of a three-stage action of the owner of the agribusiness. At the first stage, the descriptive states of the farm are collected by each employee (it is also convenient to use metaphorical images [9], in view of the possible lack of managerial skills of employees), and transform the information obtained, based on the proposed key six areas of diagnosis. Then the owner of the farm decides to correlate the description of the zones with the characteristics specified in the diagnostic tables developed by the authors of the article, this contributes to the understanding of the vision of the agribusiness staff, the allocation of certain problematic, «bottlenecks» and the enrichment of the original universal matrices by the owner of the farm, that is, a personalized approach 
to the organizational diagnosis of the object of research is formed, in addition, the share of responsibility is removed and the decision-making from the «sole» goes into the category of «collegial with the right to vote. At the third stage, the farmer must determine the complex diagnostic state of the agribusiness and develop a strategic vector based on the diagnostic data obtained [10]. The developed methodology for conducting organizational diagnostics of a farm can help the owner of the farm to predict further development or a crisis state; it will allow to quickly identify problem areas. A special role in conducting organizational diagnostics of the farm should be played by its personnel, creating a personalized base for diagnosing the object of research. In addition, the study revealed a feature related to the fact that each staff [11] unit of the farm must have a large number of competencies in order to quickly respond to changes related to weather, climatic conditions, the agro-products themselves, which are also part of the biosphere, and much more; thus, a special role not only in the diagnosis of the farm, but also in the activities of agribusiness will play the staff.

\section{Conclusions}

In the article, special universal diagnostic matrices were developed that allow us to correlate each of the 6 key zones with descriptive characteristics obtained on the basis of generalization of studies of 50 farms in the Rostov region and the Krasnodar Territory. The obtained diagnostic matrices allow farmers, who may not have a special management education, to use this mechanism to understand the results of a comprehensive analysis of the farm's activities and to act ahead of the curve, preventing possible crisis conditions, and to make decisions that allow for effective development and improvement of the farm's activities in the future.

\section{References}

1. E. Alpatova Mathematical methods in the diagnosis of the economic state of the enterprise: dissertation ... candidate of Economic Sciences : 08.00.13 / Alpatova Ekaterina Aleksandrovna; Orenburg State University, 193 (2013). http://artlib.osu.ru/web/avtoref_all/3946_20131122.pdf

2. E. Alpatova Diagnostics of the economic state of the enterprise: mathematical methods and models, Saarbrücken: LAP LAMBERT Academic Publishing is a trademark of: Omni Scriptum GmbH \& Co. KG Heinrich-Böcking-Str. 6-8, 66121, Germany, 196 (2014).

3. C.P. Alderfer The Practice of Organizational Diagnosis: Theory and Methods (New York: Oxford University Press) (2011).

4. S. D. C. Stern, A.S. Cifu and D. Altkorn Symptom to Diagnosis: An Evidence-Based Guide (New York:McGraw-Hill) (2010).

5. J. Mcfillen, D. O’Neil, W. Balzer \& G. Varney Organizational diagnosis: an evidencebased approach. Journal of Change Management, 13, 2, 223-246 (2013) http://dx.doi.org/10.1080/14697017.2012.679290.

6. B. Zarei, Y. Chaghouee, F. Ghapanchi Organizational Diagnosis in Project-Based Companies: Challenges and Directions (2014). https://doi.org/10.1177/2158244014537498

7. A. Maksimenko, O. Kovalenkova, S. Tekucheva ISPC 2019 (Ekaterinburg: Atlantis Press) 215-218(2019) 
8. M. Efimova, E. Dolgikh, T. Pershina, N. Kayumov, «Smart Technologies» for Society, State and Economy - ISC: Institute of Scientific Communications Conference, 155, 724732 (2020).

9. E. Alpatova Interactive educational technologies: methodology, theory, practice. Saarbrücken: LAP LAMBERT Academic Publishing is a trademark of: Omni Scriptum GmbH \& Co. KG Heinrich-Böcking-Str. 6-8, 66121, Germany, 205 (2014).

10. B. Upadhaya, R. Munir, Y. Blount Association between performance measurement systems and organisational effectiveness .International Journal of Operations \& Production Management. Emerald. 34(7), 853-875 (2014). doi:10.1108/ijopm-02-20130091. ISSN 0144-3577.

11. M. Karimi, R. Khodaie, Y. Chaghouee. Organizational pathology in the area of human resource productivity (Case study: Iranian Airports Company). International Journal of Advance Studies in Humanities and Social Science, 2(1), 25-50 (2014). 